Anthropos: Jurnal Antropologi Sosial dan Budaya (Journal of Social and Cultural Anthropology)

6(2) (2021): 251-261 DOI: https://doi.org/10.24114/antro.v6i2.19826

Anthropos: Jurnal Antropologi Sosial dan Budaya (Journal of Social and Cultural Anthropology)

Available online http://jurnal.unimed.ac.id/2012/index.php/anthropos

\title{
Ritual Batak Manulangi dalam Budaya Batak Sebagai Pastoral Indigenous di Huria Kristen Batak Protestan
}

\section{Manulangi Ritual in Batak Culture as Pastoral Indigenous For Batak Christian Protestan Church}

\section{Damaiyanti Sinaga*, Azwar Anas Pasaribu \& Samuel Deutschland Sigalingging}

Program Studi Magister Teologi, Sekolah Tinggi Filsafat Teologi Jakarta, Indonesia

Diterima: 09 September 2020; Direview: 28 September 2020; Disetujui: 19 Oktober 2020

\section{Abstrak}

Artikel ini bertujuan untuk menggali makna dan tujuan manulangi serta menemukan nilai-nilai kearifan lokal yang dapat dijadikan sebagai sarana pelayanan pastoral. Pendekatan pastoral melalui adat dimungkinkan untuk dilaksanakan karena orang Batak selalu terikat dengan adat, meskipun ia tinggal di kampung atau merantau ke tempat lain. Metode penelitian dilakukan dengan kualitatif dan tehnik pengumpulan data dilakukan melalui wawancara semi-terstruktur atau wawancara mendalam dan studi pustaka serta analisis data dilakukan dengan analisis mengalir, yaitu mengumpulkan, mengolah, dan menarik kesimpulan. Melalui metode tersebut ditemukan bahwa tujuan manulangi adalah untuk menghormati orangtua di akhir hidupnya, meminta berkat dan ucapan syukur. Selain itu, ditemukan nilai kekerabatan, solidaritas, dan kepedulian, kesopanan dan keterbukaan. Selain itu, nilai-nilai yang mengandung dimensi pastoral seperti; menopang, menyembuhkan dan rekonsiliasi serta membimbing. Berdasarkan seluruh nilai-nilai tersebut maka manulangi dapat diterapkakan sebagai sarana pendampingan pastoral bagi orangtua yang sakit baik karena penyakit dan usia tua dan keluarga. Serta manulangi dan perjamuan kudus, dapat diintegrasikan sebagai pelayanan pastoral yang utuh dan holistik bagi PTI dan keluarganya.

Kata Kunci: Manulangi, Nilai-Nilai Budaya, Pastoral, HKBP

\section{Abstract}

This article aims to explore the meaning and purpose of manulangi and to discover the values of local wisdom that can be used as a means of pastoral care. The pastoral approach through adat is possible because the Batak people are always bound by adat, even though they live in the village or migrate to other places. The research method was carried out by qualitative and data collection techniques were carried out through semi-structured interviews or in-depth interviews and literature study and data analysis was carried out by flow analysis, namely collecting, processing, and drawing conclusions. Through this method it was found that the purpose of the manulangi was to honor the parent at the end of his life, asking for blessings and thanks. In addition, the values of kinship, solidarity and care, politeness and openness were found. In addition, values that contain pastoral dimensions such as; sustaining, healing and reconciling and guiding. Based on all of these values, manulangi can be applied as a means of pastoral assistance for parents who are sick due to illness, old age and family. As well as prayer and communion, can be integrated as a holistic and holistic pastoral care for PTI and its families.

Keywords: Manulangi, Cultural Values, Pastoral, HKBP.

How to Cite: Sinaga, D. Pasaribu, A.A., \& Sigalingging, S.D., (2021). Ritual Batak Manulangi dalam Budaya Batak Sebagai Pastoral Indigenous di Huria Kristen Batak Protestan: Anthropos: Jurnal Antropologi Sosial dan Budaya (Journal of Social and Cultural Anthropology) 6 (2): 251-261. 


\section{PENDAHULUAN}

Pastoral atau konseling indegenous berakar dan lahir dari kearifan lokal yang dirancang bagi masyarakat dan sosial budaya suatu komunitas masyarakat yang memiliki sistem nilai-nilai, makna, dan keyakinan serta falsafah. Nilai-nilai dan falsafah hidup tersebut dapat diasimilasi dan diintegrasikan untuk membangun suatu pendekatan konseling pastoral yang kontekstual (Engel, 2016). Itsar Bolo Rangka, dalam artikelnya yang berjudul Konseling Indigenous: Rekonstruksi Konseling di Tengah Keragaman Budaya, mengatakan konsep indigenous sangat mungkin dilaksanakan mengingat masyarakat Indonesia merupakan manusia indigenous, yaitu manusia yang masih memegang teguh adat sebagai unsur utama kebudayaan. Pastoral atau konseling indigenous menekankan kearifan lokal, seperti adat-istiadat, nilai, norma dalam suatu komunitas daerah dianggap baik (Rangka, 2016). Rangka kembali menegaskan bahwa proses indigenious bertujuan untuk merekonstruksi keilmuan tertentu dan turunannya yang tepat atau cocok terhadap budaya tempat keilmuan itu diterapkan. Indigenisasi ditempuh dengan cara: pertama, indigenization from within, penerapan teori, konsep, dan metode keilmuwan konseling yang berasal dari masyarakat indigenous itu sendiri, oleh masyarakat indegenous itu sendiri, dan untuk masyarakat itu sendiri. Kedua, indigenization from without, yaitu pengembangan teori, konsep, dan metode keilmuan yang sudah ada sebelumnya tetapi murni berasal dari luar masyarakat indigenous namun diperuntukkan bagi masyarakat indigenous (Rangka, 2016).

Jonson dan Daya sebagaimana yang dikutip oleh Rangka merumuskan tiga model indigenisasi dalam konseling pastoral, yaitu; menggabungkan atau menyesuaikan pendekatan konseling tradisional yang telah ada, dengan memasukkan materi budaya dan agama sehingga dapat dibentuk perilaku yang diharapkan; pendekatan konseling yang sesuai dengan kebudayaan yang dominan di masyarakat setempat; dan mengadopsi unsur-unsur kebudayaan setempat yang masih dilaksanakan untuk dijadikan dasar pelaksanaan konseling. Dengan perkataan lain, pendekatan konseling tergantung pada perspektif budaya klien, konteks budaya, dan lingkungan kehidupan serta sumber daya yang ada (Rangka, 2016).

Dengan memanfaatkan nilai-nilai, kepercayaan dan kebudayaan dari seorang klien serta menggabungkan antara dimensi konseling pastoral dimungkinkan untuk mencapai tujuan pendampingan atau konseling pastoral yang lebih tepat. Dengan kata lain, melalui indigenous, suatu kelompok masyarakat ataupun individu yang mengalami masalah dapat dibantu dan ditolong berdasarkan pemahaman, prinsip-prinsip, dan praktik kehidupan lokal. Pendekatan indigenous ini relevan untuk dilaksanakan namun seorang konselor atau pendamping harus mau dan siap untuk belajar dari model indigenous dan berperan sebagai fasilitator sistem pendukung indigenous atau sistem penyembuhan pribumi (Sue and Sue, 2010).

Pendekatan budaya dalam pendampingan atau konseling pastoral dapat dilakukan karena budaya memengaruhi kehidupan sosial manusia, baik dalam komunitas, keluarga, spiritualitas, dan relasi mereka. Ritus dalam budaya juga mampu menangani masalah pribadi, keluarga, dan kelompok karena budaya mengandung nilai-nilai untuk mempersatukan dan perekat hubungan dan komunikasi keluarga (Lartey, 2003). Aart Martin van Beek menegaskan bahwa pendekatan konseling pastoral yang dilakukan oleh seorang konselor terhadap konselinya tidak hanya menekankan pemahaman gereja dengan dogma dan teologinya, tetapi juga dengan adatnya, meskipun keduanya harus didialogkan. Selain itu, bentuk komunikasi yang dilakukan melalui budaya atau adat 
juga lebih mudah untuk diterima oleh komunitas masyarakat adat karena adat tersebut adalah bagian dari diri mereka sendiri (Van Beek, 1987).

Salah satu ritus dari tradisi lokal masyarakat Batak yang dipraktikkan hingga masa sekarang adalah manulangi orangtua (natoras). Manulangi orangtua merupakan ritual Batak untuk memberikan makan kepada orangtua yang sakit dan hendak meninggal dunia karena sakit keras dan/atau karena usia tua. Tujuannya adalah untuk menghormati dan menyenangkan hati orangtua di akhir hidupnya. Manulangi juga dipahami sebagai media untuk memberikan berkat dan nasihat sebagai tanda tulus ikhlas bagi keturunan atau sistem kekerabatan orang Batak. Manulangi dilaksanakan berdasarkan kesepakatan keluarga orangtua yang sakit dan dilaksanakan apabila kondisinya sudah menjelang ajal, tetapi ia dalam keadaan sadar. Manulangi tidak akan terlaksana jika orangtua tidak setuju atau keluarga tidak bersatu atau sepakat (mardos ni roha). Artinya, sebelum pelaksanaan manulangi, mereka harus rekonsiliasi. Tujuan rekonsiliasi tersebut menyelesaikan masalah yang terjadi dalam keluarga mereka atau perilaku buruk dimaafkan. Selain itu, manulangi juga menjadi sarana berdoa bagi seluruh keluarga untuk meminta agar apa pun yang terjadi terhadap orangtua mereka, mereka sudah ikhlas dan sudah mempersiapkan diri.

Bertitik tolak dari hal tersebut dapat dipahami bahwa manulangi memiliki dimensi pastoral dan nilai-nilai yang dapat diakomodasi sebagai sarana pastoral untuk melayani orangtua yang sakit keras dan hendak meninggal. Oleh sebab itu, dalam tulisan ini akan dibahas sejauh mana Huria Kristen Batak Protestan (selanjutnya disingkat HKBP) memahami dan memanfaatkan ritual manulangi sebagai alat pelayanan pastoralnya dan membahas pelayanan pastoral di HKBP bagi orang sakit. Selanjutnya, bagaimana tanggapan
HKBP secara dogma, karena ritual ini berasal dari budaya. Apakah ritual manulangi mengandung unsur sinkritisme yang bertentangan dengan dogma atau pengajaran HKBP?

Pendekatan pastoral bagi orang Batak dimungkinkan untuk dilaksanakan karena orang Batak selalu terikat dengan adat, meskipun ia tinggal di kampung atau merantau ke tempat lain. Adat istiadat sebagai aktifitas sosial budaya termasuk upacara atau ritual kebudayaan berkembang menjadi tradisi dan mengandung nilai-nilai yang sulit untuk dihilangkan sehingga diturunalihkan dari generasi ke generasi berikutnya (Simanungkalit \& Rumapea, 2015). Adat tersebut termanifestasi dalam berbagai praktik yang mereka lalukan sejak masih dalam kandungan hingga ia meninggal dunia (Pasaribu, 2003).

Orang Batak sendiri lebih takut disebut tidak beradat daripada tidak beragama. Lothar Screiner mengatakan, bahwa adat merupakan kebiasaan untuk mengatur dengan kokoh segenap kehidupan ke segala segi dan dalam segala hubungan, bentuk pergaulan, penggarapan ladang, pembangunan rumah, perawatan orang sakit, penguburan orang meninggal, pendamaian, dan perkawinan (Schreiner, 1972).

\section{METODE PENELITIAN}

Metode penelitian yang dilakukan adalah penelitian kualitatif. Menurut J.W. Creswell sebagaimana yang dikutip oleh Sofyan Zaibaski dalam prosiding Metodologi Penelitian Forum Mhs Fak. Psikologi Universitas Indonesia menegaskan bahwa, penelitian kualitatif merupakan suatu proses penelitian dan pemahaman melalui metodelogi untuk menyelidiki suatu fenomena yang terjadi pada manusia di mana peneliti tersebut membuat gambaran yang tepat, meneliti kata-kata serta membuat laporan secara terperinci dari informan atau responden (Zaibaski, 2012). Penelitian ini 
menghasilkan data deskriptip baik lisan dan tertulis dari responden atau dari perilaku yang diamati (Moleong, 2007). Penelitian kualitatif menggunakan berbagai metode dan pendekatan yang memungkinkan peneliti menyelidiki dunia sosial dalam upaya untuk mengakses dan memahami dengan cara yang tepat situasi yang dihadapi oleh individu dan masyarakat (Swinton \& Mowatt, 2016). Dalam penelitian kualitatif, peneliti merupakan instrumen kunci sehingga peneliti harus mampu menangkap gejala sosial dilapangan dengan segenap fungsi inderawinya tetapi harus menganalisis secara kritis situasi atau fenomena yang sedang diteliti dan menghindari bias sehingga memperoleh data yang sahih dan mengungkap data yang tersembunyi (Mulyadi, 2011).

Teknik pengumpulan data dalam penelitian kualitatif ini adalah wawancara mendalam (in-depth interview) dengan informan atau orang yang diwawancarai. Informan yang diwawancarai adalah tokohtokoh adat dan masyarakat di Samosir, Kec. Sianjur Mula Mula, Desa Singkam, Sagala, Limbong, dan Harian Boho yang memahami dan mendalami konsep ritus manulangi, fungsi atau makna serta tata cara pelaksanaannya. Tokoh selanjutnya yang diwawancarai adalah tokoh Parmalim, yaitu M. Naipospos serta pendeta yang pernah melayani dalam ritua manulangi. Swinton menegaskan bahwa dalam proses pengumpulan data diperlukan keterampilan teknis termasuk kemampuan untuk menganalisa data dengan menggunakan kerangka kerja yang diinformasikan dan multidisiplin, kemampuan untuk mengamati, mewawancarai, menyalin dan menyajikan data dan fokus kepada sapientia (hikmat) dan scientia (pengetahuan) (Swinton \& Mowatt, 2016). Analisis data dilakukan dengan analisis mengalir, yaitu mengumpulkan, mengolah, dan menarik kesimpulan. Sebagaimana yang ditegaskan oleh Moleong yang dikutip oleh Sofyan
Zaibaski bahwa analisis data merupakan prosedur untuk merinci dan mengatur urutan data, mengorganisasikannya ke dalam suatu pola, kategori sehingga menemukan teori dari data (Zaibaski, 2012).

\section{HASIL DAN PEMBAHASAN Makna dan Fungsi Manulangi}

Manulangi merupakan ritual memberikan makan kepada orang yang disulangi. Secara umum, tujuannya adalah untuk meminta berkat dari orang yang disulangi (Vergouwen \& Mustafid, 2004). Orang Batak juga mengenal ritual manulangi yang dilaksanakan dalam berbagai konteks. Penulis akan menguraikannya secara singkat dalam bagian ini dan memfokuskan pada manulangi dalam konteks orangtua (ayah, atau ibu, atau keduanya) yang sakit. Pertama, pesta perkawinan, di mana salah seorang dari keluarga laki-laki akan manulangi orangtua mempelai perempuan untuk meminta berkat dan doa restu (Vergouwen \& Mustafid, 2004). Kedua, manulangi dilaksanakan oleh seorang anak perempuan kepada orang tuanya apabila ia tidak kunjung mendapat anak atau mengalami musibah dalam kehidupan rumah tangganya, seperti kematian anaknya secara beruntun. Ia akan manulangi orang tuanya dengan tujuan supaya ia diberkati dan dikuatkan melalui doa orang tuanya. Timbal balik dari tindakan orang tua adalah mangupa dan memberikan berkat serta mendoakan anak perempuan tersebut (Vergouwen and Mustafid, 2004). Ketiga, manulangi dilaksanakan kepada pihak yang mengalami kerugian akibat perselisihan, pertengkaran, pencemaran nama baik, dan tindakan asusila. Pihak yang melakukan pelanggaran tersebut akan melakukan manguras, mangais, mamangir (penyucian magis) dengan menggunakan jeruk purut yang bertujuan menghapus dosa, memulihkan keadaan suci, dan membersihkan. Cara ini dilakukan si 
pelanggar untuk memulihkan perasaan terluka dari orang yang ketenteramannya telah dilanggar atau disakiti (Vergouwen \& Mustafid, 2004).

Selanjutnya, manulangi orangtua yang sakit dan hendak meninggal. Manulangi orangtua dipahami sebagai simbol untuk memperlakukan orangtua dengan baik di akhir hidupnya atau simbol mengingatkan keluarga/anak-anak dari orangtua yang sakit untuk memperlakukan orangtua mereka dengan baik sebelum ia meninggal dunia (M. Sagala, 5 Januari 2020). Manulangi ini disebut juga dengan istilah sulangsulang hariapan (Vergouwen \& Mustafid, 2004) dan hanya diberikan kepada orangtua yang sudah saur matua (seluruh anak-anaknya telah menikah dan memiliki anak) atau saur matua bulung (orangtua yang memiliki anak, cucu, dan cicit). Sulangsulang hariapan dilaksanakan dirumah dan di alaman (halaman) dan melibatkan dalihan na tolu (Naipospos, 1 Mei 2020). Dalihan na tolu (selanjutnya disingkat DNT) merupakan sistem kekerabatan orang Batak atau tatanan sosial dalam tiga kelompok fungsional, yaitu dongan sabutuha (marga ayah), hulahula (marga istri), dan boru (orang-orang beragam marga dengan istri yang berasal dari satu marga). Dalam DNT, seseorang memiliki hak-hak dan kewajiban yang berbeda dalam kedudukannya sebagai anggota salah satu unsur pranata tersebut dan harus menunjukkan sikap sebagai yang dihormati atau sebaliknya pihak yang harus menunjukkan (Sihombing, 2018).

Pelaksanaan manulangi dilakukan dengan makan (marsipanganon) bersama dengan keluarga, sebab makan dalam acara ritual adat mengandung makna persekutuan yang mendatangkan keberuntungan atau kebaikan sehingga harus dilakukan dalam suasana damai dan tenang Selain itu, makan bersama atau penyajian makanan juga menjadi sarana untuk meminta berkat (pasupasu) dan perwujudan rasa hormat (Vergouwen \&
Mustafid, 2004). Secara khusus dalam ritual manulangi, makanan yang disajikan dalam ritual ini mengandung makna dan tujuan. Ikan yang disajikan kepada orang tua harus ikan simudurmudur seperti pora-pora dan ihan Batak. Mudurmudur artinya sehati, selaras, sehingga yang ditunjukkan melalui ihan itu adalah kesehatian, kekompakan, dan keselarasan hidup dalam keluarga. Mudurmudur juga berkaitan dengan harapan dan permohonan supaya seluruh keluarga seiring dan sejalan dalam pergaulan, kehidupan, dan sikap sehingga mereka memperoleh nama baik. Keluarga yang tidak memiliki sifat marudurudur akan dicela orang (M. Naipospos, 5 Mei 2020).

Manulangi sebagai suatu ritual yang dimiliki oleh orang Batak memiliki makna dan tujuan yaitu pertama, untuk menunjukkan penghormatan bagi orangtua yang sakit keras (akan meninggal). Orangtua yang sakit akan diberi makan atau disulangi oleh anak-anaknya yang dimulai dari anak sulung hingga seluruh cucu-cucunya. Setiap anak akan menyuapkan makanan kepada orangtuanya sebanyak tiga kali disertai dengan kata-kata kasih sayang (Vergouwen \& Mustafid, 2004).

Kedua, untuk memohon berkat bagi keturunan. Orang Batak menganggap bahwa orangtua merupakan Debata na niida (Allah yang bisa diihat) sehingga orangtua bisa memberikan berkat. Namun, pada masa sekarang anggapan itu sudah mulai ditiadakan sebab yang memberikan berkat hanyalah Tuhan, bukan orangtua. Tetapi, orangtua melalui manulangi memohon berkat Tuhan untuk anakanaknya (M. Sagala, 5 Januari 2020). Bungaran Antonius Simanjuntak mengatakan bahwa tradisi ini tetap terpelihara dengan baik dalam adat Batak karena konsep Kristiani yang dianggap melegalisasi adat tersebut, yakni titah kelima yaitu hormatilah ayah dan ibumu. Dengan pelaksanaan manulangi, penghormatan tersebut diwujudkan 
(Simanjuntak, 1994). Ketiga, sebagai bentuk ucapan syukur orangtua dan keturunannya atas segala berkat dan penyertaan Tuhan bagi keluarga mereka (Limbong, 4 Januari 2020).

Berdasarkan tujuan dan makna dari manulangi tersebut terdapat nilai-nilai lain yang memiliki fungsi pendampingan, seperti: pertama, nilai kekerabatan, solidaritas, dan kepedulian. Manulangi dilaksanakan berdasarkan kesepakatan keluarga, apakah orangtuanya setuju atau tidak. Jika setuju, makanan apa yang diinginkan oleh orangtua tersebut. Makanan yang diinginkan orangtua tersebut tidak bisa ditolak oleh anakanaknya. Dengan perkataan lain, mereka dengan rela akan mempersiapkan apa yang diinginkan oleh orangtua mereka. Ketidaksanggupan mereka untuk menyediakan makanan tersebut merupakan utang terhadap orangtua yang harus dibayar sebelum ia meninggal dunia (Sihombing, 1989). Dengan kata lain, keluarga kepada orangtua mereka yang sudah sakit-sakitan ditunjukkan dengan kerelaan untuk mempersiapkan makanan yang diminta oleh orangtua mereka sebagai simbol bahwa anak-anak dari orangtua yang sakit tersebut berusaha untuk menyenangkan hatinya dengan memenuhi permintaannya (Limbong, 4 Januari 2020). Orientasi kekerabatan keluarga sangat nyata dalam manulangi karena mereka membagi peran untuk mempersiapkan makanan. Dulu, pelaksanaan manulangi dibiayai oleh anak perempuan, sedangkan pihak anak laki-laki hanya sekedar membantu. Namun pada masa kini, manulangi telah dilakukan atas kesepakatan bersama (dos ni roha sibaen na saut) dan biaya ditanggung bersama oleh keluarga dan tanpa paksaan (Team Penyusun, 2009). Menurut Sihole, pembagian peran untuk mempersiapkan makanan dan duduk bersama merupakan suatu bukti bahwa mereka marsada (akur) dan tidak ada lagi masalah di antara mereka, oleh sebab itu manulangi dapat memperkuat ikatan keluarga

Desember 2019).

Kedua nilai kesopanan dan keterbukaan. Dalam ritual manulangi ini, terdapat acara khusus dalam keluarga sebelum acara adat di hadapan publik, di mana anak-anak dari orangtua yang disulangi meminta apa yang menjadi pesan terakhir bagi keturunan untuk mereka laksanakan sebagai wasiat dari orangtua mereka. Orangtua mereka akan meminta supaya anak-anaknya hidup akur, rukun, dan saling menjaga dan ia dapat menegur atau mengingatkan anak-anaknya apabila memiliki sikap tidak terpuji (Naipospos, 1 Mei 2020 ). Keluarga saling terbuka untuk mengungkapkan apa yang mereka rasakan dan alami, baik permasalahan dalam keluarga maupun yang terkait secara khusus dengan hubungan-hubungan yang tidak akur dan disampaikan dengan menggunakan kata-kata yang santun, hormat, dan terbuka. Selain itu, mereka bisa menginstropeksi diri mereka masingmasing.

Ketiga, manulangi sebagai sarana untuk saling menopang. Manulangi juga tidak terlepas dari pemahaman orang Batak tentang tondi (roh), di mana jika seseorang sakit, tondi-nya juga lemah. Oleh sebab itu, tondi orang sakit tersebut harus dikuatkan oleh keluarganya melalui manulangi. Namun, konsep manulangi yang telah dipengaruhi kekristenan, menguatkan tondi tersebut tidak hanya mewujudkan harapan dan keinginan dari orang-orang yang memberi makan tetapi ritual tersebut merupakan dalan laho martangiang (sarana untuk mendoakan), supaya orangtua yang sakit tersebut kuat dan tetap berpengharapan dalam sakit yang ia alami. Seperti yang disampaikan oleh Sihole, jika penyakit tersebut yang akhirnya menyebabkan orangtua tersebut meninggal, keluarganya telah menyerahkannya dalam doa kepada Tuhan (Sihole, 31 Desember 2019). Manulangi sebagai sarana berdoa bagi Tuhan dapat dipahami juga sebagai doa reflektif untuk 
berkomunikasi dan mengungkapkan keluh kesah kepada Tuhan di mana keluarga tidak hanya melibatkan Tuhan tetapi memperoleh ruang untuk mengungkapkan keinginan harapan dan emosi, serta mendengar suara dan kehendak Allah yang mampu menguatkan keluarga secara mental dan spiritual (Messakh, 2019).

\section{Keempat, manulangi sebagai} sarana untuk menyembuhkan dan rekonsiliasi. Esensi menyembuhkan dalam manulangi yang penulis maksud adalah memulihkan relasi atau hubungan di antara sesama anggota keluarga dan orangtua. Penyembuhan relasi ini juga berkaitan dengan dimensi rekonsiliasi. Masalah internal keluarga atau masalah tanggung jawab untuk menjaga, merawat, dan mengobati orangtua yang sakit juga dapat mengakibatkan rusaknya hubungan keluarga. Selain itu, kerelaan untuk melepas orangtua sukar dilaksanakan karena kelekatan antara orangtua dan keluarganya. Berbagai dinamika ini dapat membuat sistem keluarga terganggu dan relasi-relasi menjadi rusak. Oleh sebab itu, keluarga dan orangtua membutuhkan rekonsiliasi atau penyelesaian atas masalah yang belum selesai. Namun, dalam ritual manulangi membuka ruang bagi keluarga untuk saling memaafkan dan mengampuni, bukan hanya terhadap orangtua di penghujung usia tetapi juga terhadap sesama mereka. Sebelum pelaksanaan manulangi, atau sebelum orangtua yang sudah sakit tersebut akan disulangi, seluruh keluarga duduk bersama untuk saling mengungkapkan isi hatinya kepada orangtua mereka, di mana anak-anaknya akan meminta maaf atau mengaku salah apabila melakukan kesalahan yang disengaja atau tidak disadari yang menyebabkan kekecewaan bagi orangtua mereka. Biasanya dalam ritual ini akan disampaikan suatu pernyataan untuk meminta maaf yaitu "Gundur ma pangalumi, ansimun pangalambohi; hasalaan di hata pangalaho, pambahenanku, sai sahalam dohot tondim ma mangalambohi" (labu menenangkan, mentimun menyegarkan, kesalahan lewat kata-kata dan perbuatan, kiranya dimaafkan). Dalam tahap itu, orangtua yang disulangi juga ikut meminta maaf, jika ada kesalahannya kepada anak-anaknya (Pasaribu, 2003). Menurut penulis, dengan duduk bersama dimungkinkan sebuah konseling keluarga yang dapat saling menguatkan satu sama lain, sehingga beban kesedihan yang mereka alami dan rasakan akibat kondisi orangtua mereka yang sudah sakit parah dan akan meninggal ditanggung bersama-sama dan dapat dilewati secara bersama-sama juga.

Kelima, manulangi sebagai sarana untuk membimbing. Pelaksanaan ritual manulangi selalu di awali dengan ibadah yang di pimpin oleh Pendeta. Pendeta atau pelayan dapat melakukan bimbingan rohani kepada orangtua yang sakit, keluarganya dan orang-orang yang ikut hadir dalam ritual tersebut (Hutapea, 24 Januari 2020). Kehadiran gereja juga tidak terlepas dari sikap dan pandangan HKBP yang terbuka terhadap ritual manulangi atau secara umum terhadap adat dan budaya. Dalam dogmanya, HKBP mengemban misi untuk menggarami budaya Batak dan dipertegas kembali dalam dokumen pengakuan iman HKBP yang sudah disusun pada tahun 1951 dan di rumuskan kembali pada tahun 1996. Dalam pengakuan iman tersebut, HKBP merumuskan sikapnya tentang kebudayaan, yaitu, "sebagaimana yang sudah ditentukan dalam Pengakuan Iman HKBP tahun 1951 dan tahun 1996, bahwa Allah menciptakan manusia dengan tempat tinggalnya dan tempatnya bekerja di dunia ini (kejadian 2:5-15). Dialah yang memiliki semuanya, yang memberikan kehidupan bagi semua yang diciptakanNya. Tempat manusia bekerja adalah daratan, laut dan langit/ruang angkasa. Allah memberikan kuasa kepada manusia untuk memelihara dunia ini dengan tanggungjawab penuh. Dia juga memberikan bahasa, alat-alat musik, kesenian, dan pengaturan kepada manusia 
sebagai alat manusia dan juga aturan untuk memuji Allah dan sebagai sarana untuk memelihara dan memperindah persahabatan antar manusia agar melalui kebudayaan, kerajaan Allah semakin besar. Tetapi kebudayaan yang bercampur kekafiran dan yang bertentangan dengan Firman Allah ditolak" (HKBP, 2011).

Pengakuan iman ini merumuskan sikap HKBP yang menolak kebudayaan yang bercampur bertentangan dengan firman Allah. Manulangi tetap dilaksanakan, karena tidak ada unsur kekafiran atau melibatkan roh-roh nenek moyang. Makanan yang disajikan dalam ritual tersebut dipandang tidak mengandung unsur magis. Oleh sebab itu, gereja hadir dan terlibat dalam ritual ini untuk melakukan bimbingan secara rohani dan pendeta dapat mempertegas sikap menghormati orang tua sebagai perwujudan melaksanakan firman Tuhan sehingga kehadiran gereja tidak hanya sebagai tempelan tetapi ibadah adalah bagian dari manulangi itu sendiri.

Merujuk pada pemahaman tersebut diatas, maka dapat disimpulkan bahwa manulangi mengandung nilai-nilai kebaikan dan dimensi pastoral. Jika dibandingkan dengan fungsi pastoral yang diuraikan oleh William A. Clebsch dan Charles R. Jaekle sebagaimana yang dikutip oleh Hendri Wijayatsih bahwa pendampingan pastoral memiliki empat fungsi yaitu; menyembuhkan yang berfungsi untuk menolong sesama dalam mengatasi derita fisik; menopang, upaya pastoral untuk membantu orang yang menderita untuk bertahan menghadapi masalahnya; membimbing yaitu untuk menolong atau membantu individu untuk mengambil sebuah keputusan secara mandiri; mendamaikan yaitu untuk memperbaiki dan membarui kembali hubungan yang rusak antara manusia dengan sesamanya dan dengan Tuhan (Wijayatsih, 2011). Dengan demikian, manulangi dapat diakomodasi sebagai alat bantu pastoral

\section{Pelayanan Pastoral di HKBP dan Manulangi}

Konseling dan pendampingan pastoral merupakan salah satu tugas pelayanan gereja HKBP dan melaksanakan tugas tersebut berdasarkan tugas dan tanggung jawab pelayan-pelayan tahbisan. Pelayanan ini dilakukan dengan mengunjungi dan mendoakan jemaat yang sakit baik di rumah maupun di rawat di rumah sakit dan pelayanan perjamuan kudus. Pelayanan perjamuan kudus di HKBP dilaksanakan di gereja dan di rumah khusus bagi yang tidak bisa hadir ke gereja dan tata ibadah diatur dalam Agenda HKBP atau Tata ibadah HKBP. Dalam tata ibadah perjamuan kudus tersebut dihubungkan dengan pelayanan Firman atau khotbah. Khotbah dapat berfungsi untuk menguatkan dan menyembuhkan dan doa syafaat, di mana orang yang menerima perjamuan kudus diminta untuk mengingat apa yang terjadi dalam konteksnya dan membawa doanya kepada Allah (Pakpahan, 2014).

Secara khusus pelayanan perjamuan kudus bagi orang sakit sejatinya bukan pelayanan untuk melegitimasi kematian dari orang yang menerima perjamuan tersebut tetapi sebagai peneguhan iman kepada Tuhan. Hal tersebut dapat dilihat dalam formula perjamuan kudus bagi orang sakit yang mendorong orang yang menerima perjamuan untuk mengakui segala dosanya di hadapan Tuhan. Formula perjamuan kudus juga meneguhkan iman orang sakit dan keluarganya dan penghiburan bagi orang yang berduka serta kekuatan bagi orang yang lemah. Selain itu, perjamuan kudus juga mendorong orang sakit untuk mengampuni, sesuai dengan formula yang ada dalam Tata Ibadah atau Agenda HKBP "Ampuni semua orang yang bersalah kepadamu, supaya Allah mengampuni dosa-dosamu." Dengan demikian, perjamuan kudus tidak hanya memberi kesempatan untuk berdamai dengan Tuhan tetapi juga dengan orang lain dan waktu untuk berkumpul/bersekutu. 
Pertemuan tersebut dapat bermakna untuk melatih kembali hubungan persekutuan dan mengkomunikasikan rekonsiliasi yang dibutuhkan (Roberts, 1995).

Orang yang sakit diminta untuk mengampuni orang yang bersalah kepadanya. Pengakuan akan pengampunan tersebut harus direalisasikan kepada orang yang bersalah kepadanya. Dengan perkataan lain, perjamuan kudus ini mendorong orangtua yang sakit untuk memulihkan relasi-relasinya, supaya ia layak menerima makan perjamuan kudus. Selanjutnya, dengan menerima perjamuan kudus, orang yang menderita penyakit akut atau menjelang ajal diteguhkan dengan firman Tuhan sehingga ia memiliki rasa damai. Seperti yang dinyatakan oleh Alexander Schmeman, penyakit bisa membuat seseorang merasakan kekalahan, kejatuhan, keputusasaan, dan kesunyian. Tetapi di sisi lain, kondisi tersebut bisa menjadi sebuah jalan kemenangan utama dalam kehidupannya. Gereja datang bukan untuk menjadikan ia sehat tetapi untuk membawanya ke dalam cinta Tuhan (Schmeman, 2004). Namun, ruang untuk saling mengampuni tersebut tidak dimuat dalam tata ibadah kecuali atas inisiatif dari pendeta yang melayani. Oleh sebab itu, manulangi bisa mengisi kekosongan yang ada dalam perjamuan kudus untuk menyembuhkan relasi orangtua yang sakit dengan anggota-anggota keluarganya. Manulangi membuka ruang bagi keluarga untuk saling terbuka, saling memaafkan, dan saling mendoakan, baik terhadap orangtua yang akan menerima perjamuan kudus maupun bagi sesama mereka. Manulangi sebagai pelayanan keluarga yang dilakukan secara kekeluargaan atau internal keluarga membuat mereka bisa saling mengungkapkan apa yang mereka rasakan. Dalam proses seperti itu, dengan ritual manulangi mereka bisa melaksanakan kewajiban mereka sesuai dengan adat, yaitu memberikan penghormatan mereka kepada orangtua mereka yang sakit dan menata kembali relasi-relasi di antara mereka. Sesudahnya, seluruh proses akan diakhiri dengan merayakan perjamuan kudus. Dengan demikian, seperti yang disampaikan oleh Pdt. Harris Tanda Huria Sitorus, upaya saling memaafkan atau mengampuni dan rekonsiliasi dalam keluarga yang terjadi dalam manulangi dilaksanakan dengan didasarkan pada dan dikuatkan oleh firman Tuhan yang diberitakan melalui perjamuan kudus (Sitorus, 25 April 2020). Begitu juga dengan Pdt Agustin Hutapea berpendapat bahwa manulangi seperti sebuah ritual perpisahan dalam keluarga. Perpisahan itu sebuah keadaan yang sulit bagi keluarga dan tidak semua orang sanggup menerima manulangi dalam hidupnya karena tidak ada orang yang benar-benar siap untuk bertemu Jahowa Mulajadi Nabolon (Tuhan), baik keluarga maupun orangtua yang sakit keras. Oleh sebab itu, ritual tersebut harus dimulai dengan kebaktian dan diakhiri dengan perjamuan kudus untuk menguatkan keluarga dengan firman Tuhan, sehingga manulangi tersebut merupakan sebuah sarana untuk mendoakan keluarga (Hutapea, 24 April 2020).

Dengan demikian, menurut penulis, manulangi dan perjamuan kudus -dengan tanpa mengurangi makna esensial dari perjamuan kudus- akan dapat berjalan beriringan dan saling melengkapi, demi kepentingan pelayanan pastoral secara holistik kepada orangtua tersebut dan keluarganya. Oleh karena itu, dengan memberdayakan manulangi atau mengakomodasi manulangi maka ritual manulangi ini dapat dijadikan sebagai pelayanan pastoral. Dengan kata lain, manulangi membantu HKBP dalam menjalankan pelayanan pastoralnya kepada orangtua dan keluarganya, karena melalui manulangi keluarga dipandang dan diperlakukan sebagai satu tim yang utuh dan kompak. Dalam sistem keluarga yang demikian, setiap individu anggota keluarga dapat menjadi pelaku yang berperan sebagai pendamping, bahkan konselor, bagi 
sesama anggota keluarganya, terutama bagi orangtua mereka yang sakit parah. Bahkan sebaliknya, dalam arti dan tingkat tertentu, orangtua tersebut dapat menjadi konselor bagi anggota-anggota keluarganya. Melalui sistem ini, mereka bisa saling menopang dan menguatkan satu dengan yang lain, dengan melibatkan orangtua. Orangtua menjadi subjek dan bukan sekedar objek pelayanan pastoral. Dengan perkataan lain, penggunaan ritual manulangi sebagai bagian dari konseling pastoral menekankan bahwa pendampingan dan konseling bukan hanya dilakukan oleh individu atau konselor profesional yang terlatih (baca: pendeta), tetapi dapat juga dilakukan oleh anggotaanggota keluarga melalui ritual manulangi yang mereka lakukan. Dalam hal ini, sebagai persiapan manulangi, pendeta harus mengadakan percakapan pastoral secara khusus dengan anak-anak untuk membekali mereka agar mereka dapat berperan secara positif dalam pelaksanaan manulangi.

\section{SIMPULAN}

Manulangi merupakan pelayanan perjamuan yang dilakukan oleh keluarga melalui adat yang bertujuan untuk menunjukkan rasa hormat, kasih sayang, dan penghargaan mereka kepada orangtua serta bentuk ucapan syukur kepada Tuhan. Manulangi mengandung nilai-nilai kebaikan dan dimensi pastoral yang relevan untuk diaplikasikan bagi keluarga yang melaksanakannya. Berdasarkan sikap dan pandangan HKBP yang terbuka terhadap manulangi, maka manulangi dapat dijadikan sebagai sarana pastoral dilatarbelakangi oleh beberapa motif. Pertama, HKBP dapat menerima ritual manulangi sebagai warisan budaya yang bermanfaat dan tidak bertentangan dengan iman Kristen. Kehadiran gereja untuk membuka ibadah dan melakukan bimbingan rohani keluarga. Kedua, manulangi dapat memperat dan memulihkan hubungan dan relasi keluarga serta memantapkan motivasi keluarga untuk menghormati orangtua, bukan hanya karena manulangi tetapi karena perintah Tuhan yang melegalisasinya. Ketiga, manulangi dapat memperlengkapi pelayanan perjamuan kudus di HKBP. Jika manulangi diberdayakan secara efektif akan menjadi sumbangan yang berharga bagi pelayanan pastoral indigenous atau berbasis budaya atau kearifan lokal di HKBP.

\section{UCAPAN TERIMAKASIH}

Penulis mengucapkan terima kasih kepada orangtua, teman-teman seangkatan di kampus dan secara khusus kepada seluruh responden dalam penelitian ini.

\section{DAFTAR PUSTAKA}

Engel, J. D. (2016). Konseling Pastoral dan Isu-Isu Kontemporer. Jakarta: BPK Gunung Mulia.

HKBP. (2011). Pengakuan Iman HKBP 1951 dan 1996. Pearaja: Kantor Pusat HKBP.

Lartey, E. Y. (2003). In Living Color: An Intercultural Approach to Pastoral Care and Counseling. London: Jessica Kingsley.

Martin van Beek, A. (Ed.). (1987). Konseling Pastoral: Sebuah Buku Pegangan Bagi Para Penolong di Indonesia. Semarang: Satya Wacana.

Messakh, B. J. T. (2019). Dimensi Pastoral Dalam Doa: Menemukenali Praktik Doa yang Bertanggungjawab Dalam Pelayanan Pendampingan dan Konseling Pastoral, Jurnal Abdiel, 3 (2): 33-45.

Moleong, L. J. (2007). Metodologi Penelitian Kualitatif. Bandung: Remaja Rosdakarya.

Mulyadi, M. (2011). Penelitian Kuantitatif dan Kualitatif serta Pemikiran Dasar Menggabungkannya, Jurnal Komunikasi dan Media, 15 (1): 127-138.

Pakpahan, B. (2014). Analisis Kritis Liturgi Perjamuan Kudus Huria Kristen Batak Protestan, Indonesian Journal of Theology, 2 (1): 42-64.

Pasaribu, J. B. (2003). Adat, Agama dan Budaya Batak: Saluran Kasih Sesama. Jakarta: Yayasan Pustaka Obor.

Rangka, I. B. (2016). Konseling Indigenous: Rekontruksi Konseling di Tengah Keragaman Budaya. Seminar Bimbingan dan Konseling. Padang. 19-20 Maret.

Roberts, H. W. (1995). Pastoral Care Through Worship. Macon: Smyth \& Helwys. 
Schmeman, A. (2004). For the Llife of the World: Sacraments and Orthodoxy. Crestwood, N.Y: St. Vladimir's Seminary Press.

Schreiner, L. (1972). Telah Ku Dengar dari Ayahku. Jakarta: BPK-GM.

Sihombing, A. A. S. (2018). Mengenal Budaya Batak Toba Melalui Falsafah "Dalihan Na Tolu" (Perspektif Kohesi dan Kerukunan), Lektur Keagamaan, 16 (2): 347-371.

Sihombing, T. M. (1989). Jambar Hata: Dongan tu Ulaon Adat. Medan: Tulus Jaya.

Simanjuntak, B. A. (1994). Konflik Status dan Kekuasaan Orang Batak Toba: Bagian Sejarah Batak. Jakarta: Yayasan Pustaka Obor.

Simanungkalit, A., \& Rumapea, M. E. (2015). Dampak Modernisasi terhadap Upacara Adat Perkawinan Masyarakat Batak Toba di Kota Medan. Jurnal Antropologi Sosial dan Budaya, 1 (2): 167-174.
Sue, Derald Wing, and David Sue. (2010). Counseling the Culturally Diverse: Theory and Practice. USA:John Wiley and Son Inc.

Swinton, J., \& Mowatt, H. (2016). Practical Theology and Qualitative Research. London: SCM Press.

Team Penyusun. (2009). Ruhut-Ruhut Paradaton. Jakarta: Kata Hasta.

Vergouwen, J. C., \& Mustafid, F. (2004). Masyarakat dan Hukum Adat Batak Toba. Yogyakarta: LKiS.

Zaibaski, S. (2012) Analisis dan Pengolahan Data Kualitatif. Seminar Metodologi Penelitian, Universitas Indonesia. Depok, 2012, April 15.

Wijayatsih, H. (2011). Pendampingan dan Konseling Pastoral, Jurnal Gema Teologi, 35 (1/2): 1-7. 